\title{
補潟迎随手法による neurometry の変化（そのI)
}

\section{㧕制の良導絡への随法手法による変化}

関西銊尒短期大学

森川和宥、北村 智、吉備 登

王 財源、遠藤 宏、武内哲郎

I 、はじめに

銊炎治療の処方構成には本治法（全体治療） と標示法（局所治療）があり、診察・検査情報 から分析することで選別される。そのなかで本 治法は、気脈の調整を目的としており、経絡の 不調和を調整することが重要とされている。

この経絡の調整には、その経の虚実やつほの 虚実を把握して行なわれるわけ で、古典では補瀉の手法が用い られ、虚するものは補い、実す るものは瀉するというのが定法 である。

文字の上から“補”は与える、 益す、興す、加える、救う、と いうことになり、“瀉”は取る、 奪う、滅ずる、抑える、などと いうことになる。現代的に考え れば、“補”は「生命力の恒常 性維持能力を助長する」ことと なり、“鴪”は「生命力の恒常 性維持能力を阻害するものを除 く」こととなる。

すなわち、生命の全生機を盛 んにし、原気を振興し（補）病 的なものを解消し、除去する (瀉)ということになる。

鋮の補瀉の名称には、陰陽・ 呼吸・鍼尖・提按・開闑・迎 随・用捨・出内・弾爪・摇動な ど（表 1) があり、その目的と する補瀉ができたか否かは、刺 鍼前の脈その他の身体的状態と 刺鋮後の状態とを比較している。
しかし、良導絡に当てはめると機能立進を抑 制させ、機能低下に対して機能を充進させるこ とに相当する訳である。その良導絡治療におい ては、NEUROMETRYに基づいて、皮處の交 感神経の興奮性を数值で眺め、興奮側・抑制側 に出現している異常の良導絡の興奮点・抑制点 に、EAPでは直流 $200 \mu \mathrm{A} 7$ 秒間通電、炎では

\begin{tabular}{|c|c|c|}
\hline 鬴润の名称 & 㭪 の 手技 & 潅 の 手 \\
\hline 陵 & 脚扁は禣う & 䧄病は酒す \\
\hline 爱 & 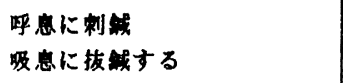 & 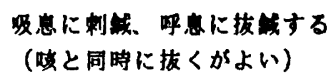 \\
\hline 尖 & 调を盟めて用う & 戴を滥めすに用う \\
\hline 按 & 穴所を爪て强く押えて制入す & 穴所を圧せすして制入す \\
\hline 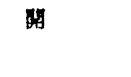 & 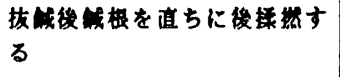 & 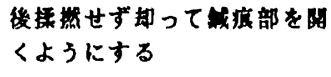 \\
\hline 避 & 树格に従って代をせて代す & $\begin{array}{l}\text { 泽絡に逆らって战を伏せて制 } \\
\text { す }\end{array}$ \\
\hline 拾 & 钿て剌入す & 多少清みても刺入す \\
\hline 出 内 & 馀制除抜，正気を集める & 速制速抜，邪気をもらす \\
\hline 用, 不及 & 房人の攵根の羽をに强く刺す & 扁人の攵根强をに强く刺す \\
\hline 彈 & 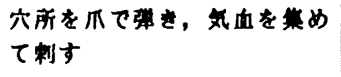 & 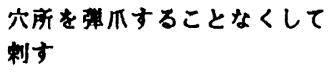 \\
\hline 播 & 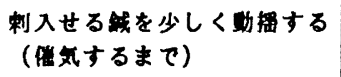 & 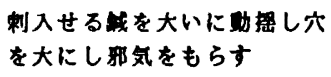 \\
\hline 溇 & 浇く制す & 濯く制す \\
\hline 太 & 第い紟を用いる & 太い㗅を田いる \\
\hline 子母方円 & 感せる絟の母を禣う & 央する綪の子を酒す \\
\hline
\end{tabular}

表 1 鋮の補瀉の手法 
半米粒大 3 壮を用いて調整する訳である。その 調整ができたか否かは、再度NEUROMETRY を行なうことで、客観的に数值の変動によって 把握することができる。

この調整法に代わって、古典の補瀉の手法を 用いたとき、皮虚の交感神経の興奮性にどのよ うな変化をもたらすかを、NEUROMETRYに よって眺めている。

そこで、数ある銊の補㴼の手法の中より、補 瀉迎随を取り上げた。今回は、経気の流れに沿 った刺入方法すなわち「随法」を用いたときに、 良導絡の興抑がどれだけ調整されるかについて 検討したので報告する。

\section{II、対象および実験方法}

\section{1) 対象}

大阪医大ペインクリニック外来に訪れた患者 27名を対象に、男性17名、女性10名を取り扱っ た（図1）。取り扱った患者の訴えは腰痛 5 名、 首の痛み・肩凝り 4 名むちうち・頭痛 3 名で、 その他では乳部痛・顔面痛・書痤・メニエルな どであった。

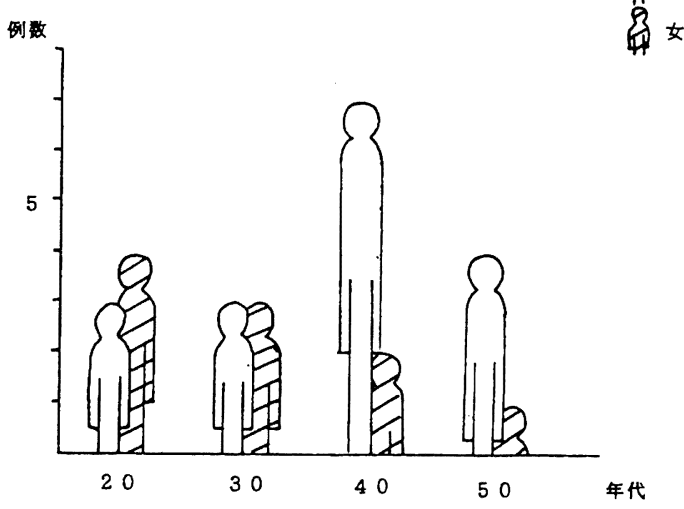

図 1 取り扱った年代と性別

\section{2 ）実験方法}

患者を 10 分間安静にさせた後、手足の特定測 定部位を計測して、その数值を良導絡専用カル テにプロットし、臨床的生理的範囲を求め、異 常の良導絡を見いだした。

生理的範囲より逸脱している異常の良導絡の なかで、抑制側に出現している良導絡を求めた。
この抑制側に出現している良導絡に対し、その 良導絡が走行している前腕部および下腿部の中 央部に随法の手法を施した。

すなわち 抑制している良導絡上に古典の経 絡の流れに沿って「随法」を施した。用いた鍼 は $48.5 \mathrm{~mm} \quad 0.20 \mathrm{~mm}$ の鍼で、皮店面に対し 15 度以内の横刺で $2 \mathrm{~cm}$ の刺入を行い、10分間置 銊をした。

なお、前腕部および下腿部の中央部には横線 の印を入れておき、この線を中心に刺入した。

計測にはノイロメーターD401型の改良型を 用い、 $12 \mathrm{v}$ 陰極 $200 \mu \mathrm{A}$ にアジャストして、直 前・刺入 10 分後 $\cdot 30$ 分後に皮虐通電抵抗電流数 値を計測した。

室温は $26 \pm 2$ 度、湿度は $60 \pm 3$ であった。

\section{III実験結果}

1）全良導絡測定平均値の変動

良導絡の測定数値を各良導絡毎に平均值およ び偏差值を算出し、それを良導絡カルテにプロ ットした。全良導絡測定数值のバラツキは、直 前に比して10分後・30分後には調整されている 傾向が見られた（図-2）。

\section{2 ) 随法による抑制側の変動}

随法を施した良導絡の変動では、10分後は $43.6 \%$ に興奮が見られ、 $52.6 \%$ は変化がなかっ たが、30分後では50.6\%に興奮が見られ、47.4 \%は変化がなかった。（図-3）

\section{3 ）興奮側の変動}

一方、刺激を加えなかった興奮側の異常の良 導絡に、どのような影響を与えているかについ て眺めた結果、10分後では $52,2 \%$ に抑制が見ら れ、30分後では $54,7 \%$ に抑制が見られたが、そ のなかで $\mathrm{H}_{1}-\mathrm{H}_{3}$ の抑制が10分後および30分後と もに多く見られた。これは、北村がおこなった 因子分析による $\mathrm{H}_{1}-\mathrm{H}_{3}$ の相関性の変化と一致し ている。(図-4) 


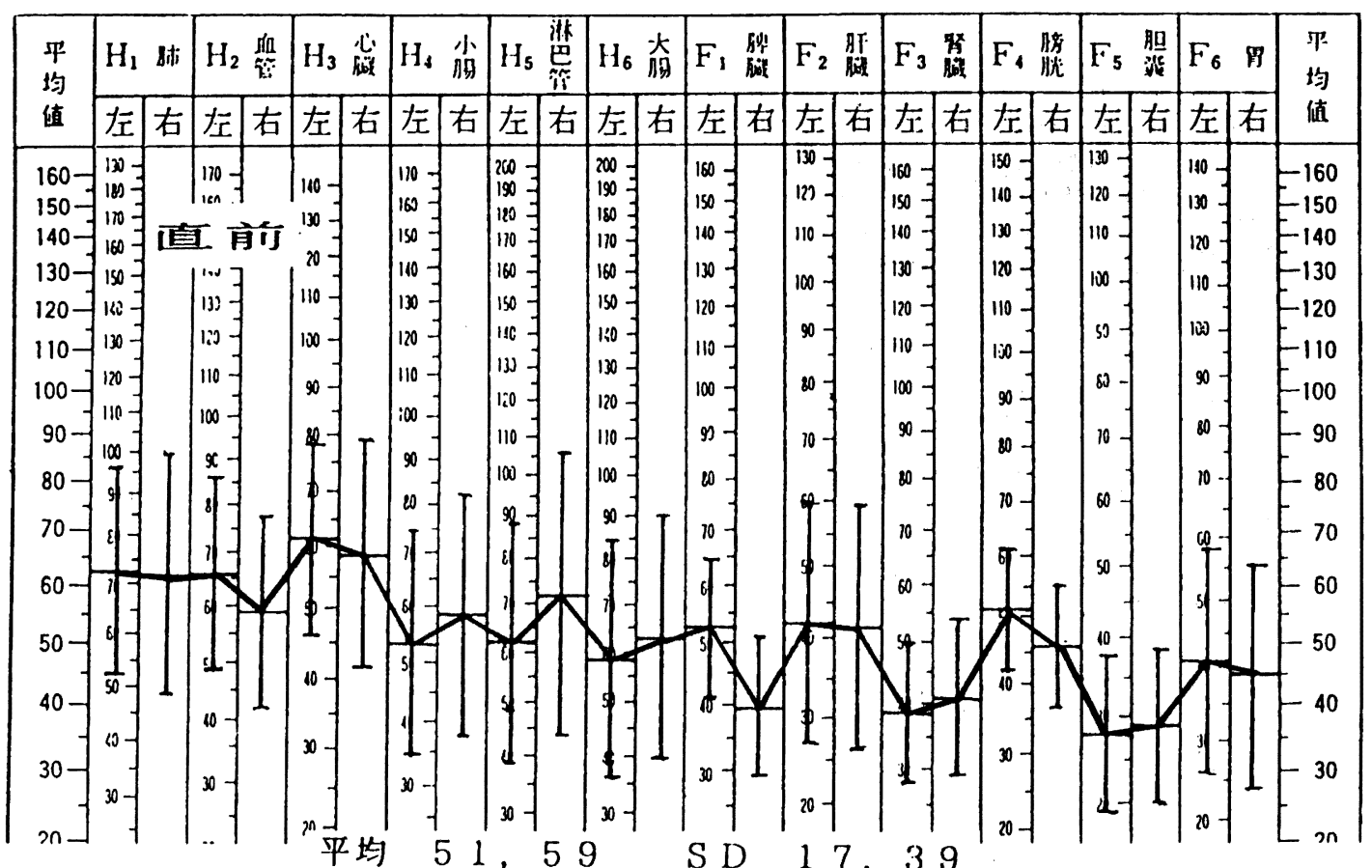

平均 51,59 S D 17,39
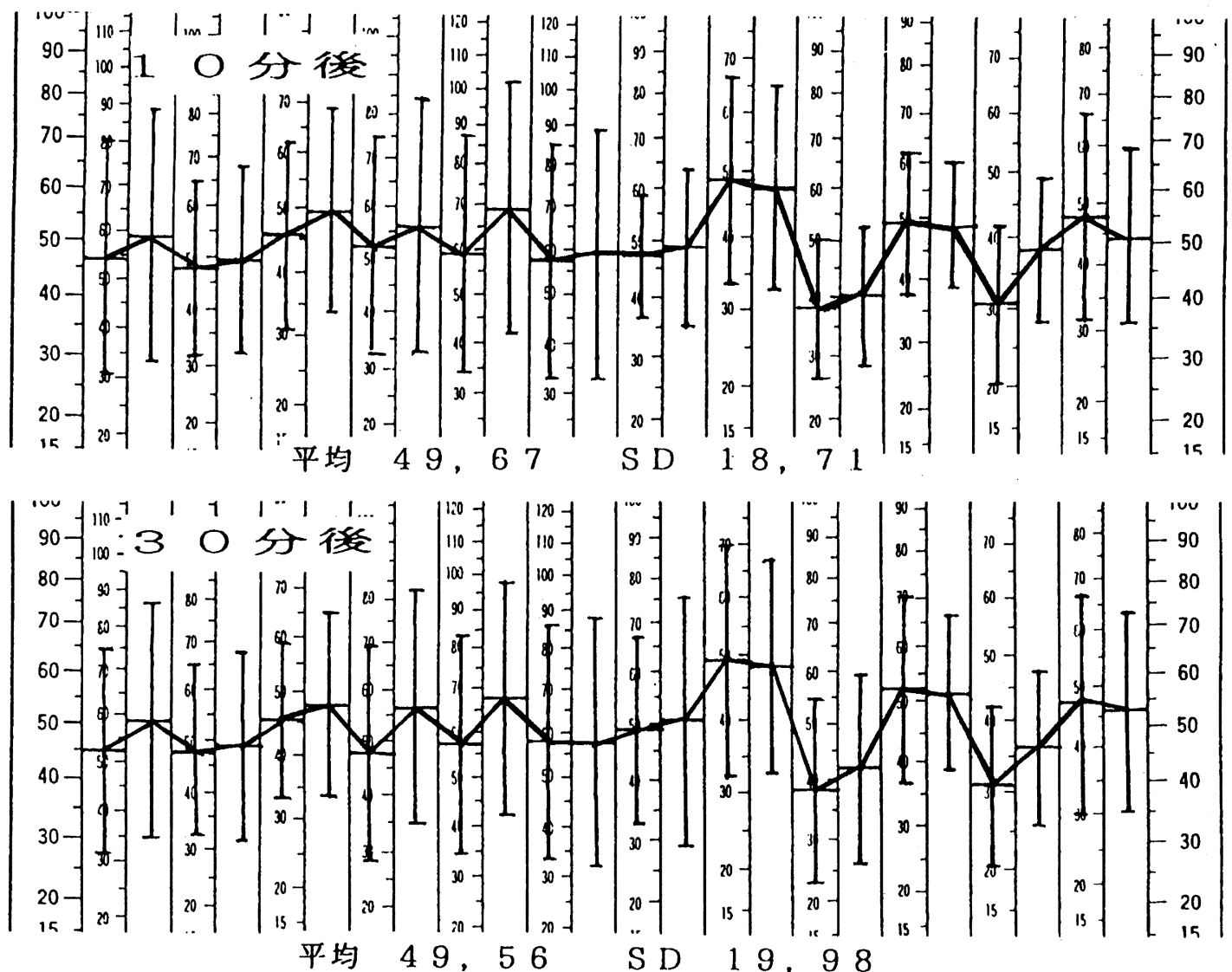

図 2 全良導絡測定平均值の変動 


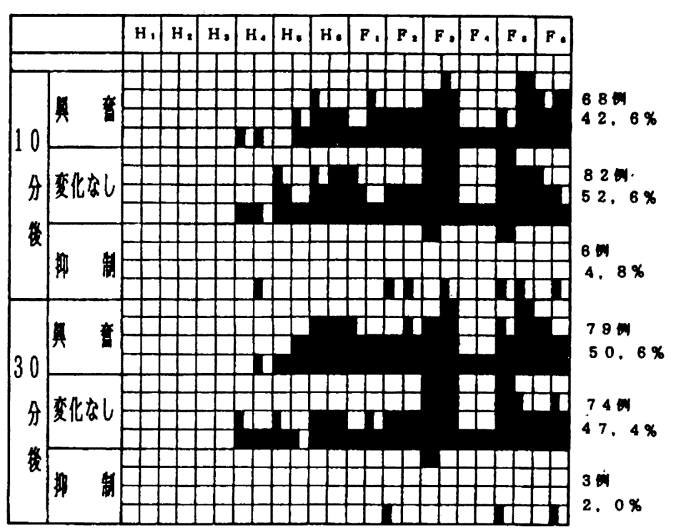

図 3 異常良導絡の抑制に随法をした抑制の変動

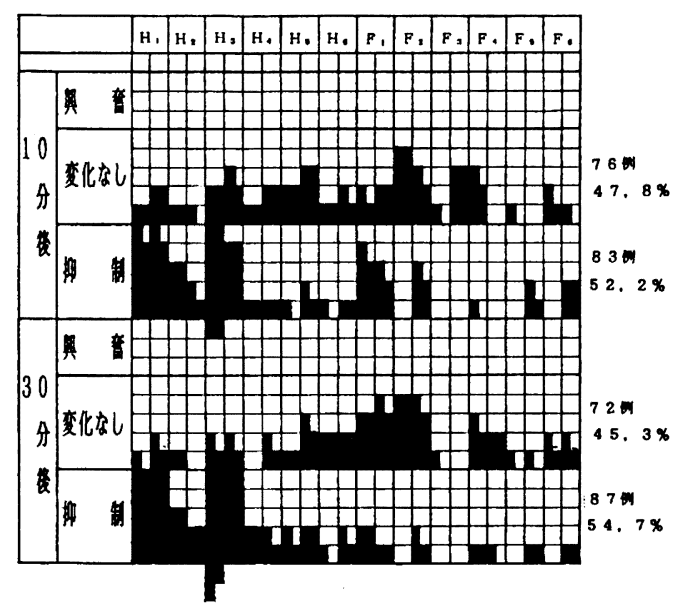

図 4 異常良導絡の興音側の変動

\section{4）全良導絡平均值の変動}

随法を施すことで、全良導絡の平均值がどの ように変化しているかを $\mathrm{t}$ 検定を用いて検討し たが、10分後および30分後ともにあまり変化が 見られなかった。（図 5)

\section{5 ）バラツキ幅の変動}

チャートのバラツキとして、最も高い数值と 最も低い数值の距離間の変化を $\mathrm{t}$ 検定で眺める と、10分後・30分後にやや狭まりが見られる程 度であるが、偏差値幅は縮小されている。(図6)
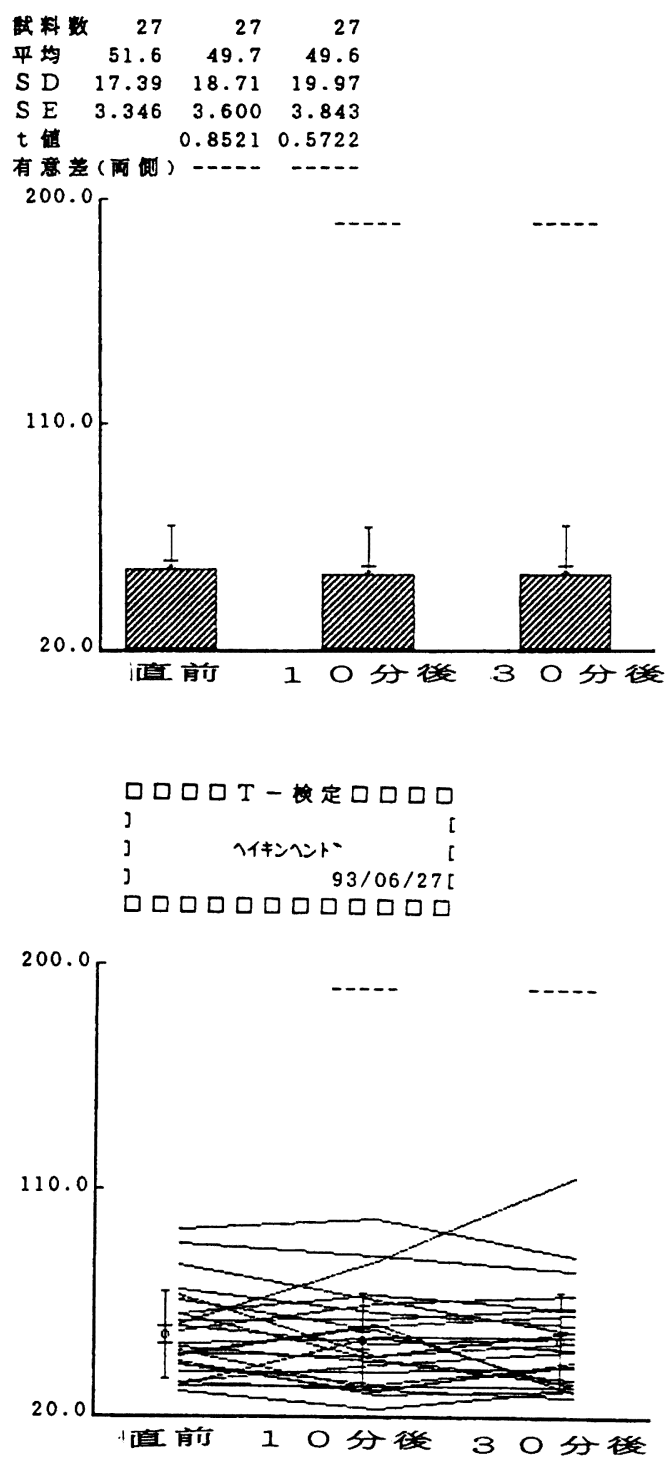

図 5 全良導絡平均値の変動 

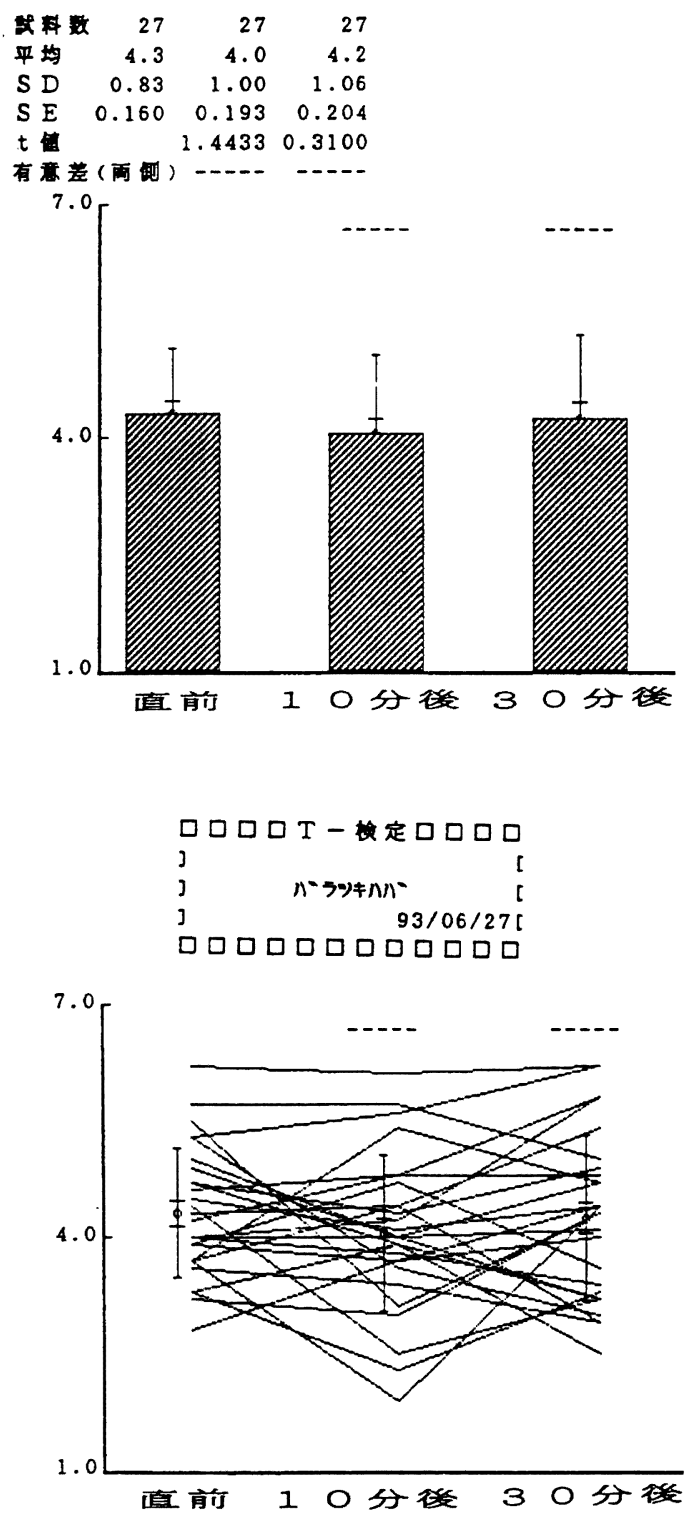

図 6 バラツキ幅の変动

\section{N、まとめ}

経絡には虚実があり、良導絡にあてはめると 良導絡の興奮性であり、病的に興奮性が高いの
が実、病的に興奮性の低いのが虚に相当する。 これを健康状態の興奮性に調整することが治療 である。この虚実を調整するのが良導絡の調整 法であり、古典の補瀉である。

古典における鍼炎治療の補瀉は、脈診の状態 や身体症状などの情報で決定される。その情報 で決定された証に適応する手法が、補瀉の手技 のなかから弁別され、治療が行われる。

治療後における補瀉の効果を診る材料は、脈 診や望診あるいは触診による主観的なものが一 般的である。しかし、良導絡治療においては、 neurometryを経時的に行なうことで、興奮・ 抑制の調整が客観的に捉えることができる。

良導絡は、単に古典を科学的に立証したもの でなく、単純統計学にしろ、臨床を通じて統計 を行い、古典のよい部分を取り入れた訳である。 いいかえれば、良導絡を通じて古典を理解する ことができると言える。

そこで、われわれは、古典の補潟の手技が、 良導絡治療のうえにどのような変化をもたらす かについて、neurometryによる皮膚通電抵抗 電流量数値の変動を用いて検討している。

今回は、抑制側に出現した異常の良導絡に随 法を行なった訳であるが、随法を行なった良導 絡の約半数に興奮が見られ、残り半数に変化が なかった。このことは、中焦から起こる経絡の 流注の流れのあることが示唆され、中谷が報告 している自律神経の機能との関連が考えられる。 そして、異常の良導絡の調整は、従来の調整方 法とともに、古典の手技を加えることができる と推測できる。

また、補瀉を行なわなかった $\mathrm{H}_{1}-\mathrm{H}_{3}$ では抑制 されていることは、北村らが行なった因子分析 での相関性と類似している。

今後、一つの良導絡での手技あるいは刺入方 法を考慮して、古典の手技が良導絡治療に活用 できるかを検討していきたい。 